\title{
Analysis of Forest Cover Loss in Wilpattu Forest Complex: A Remotely Sensed Change Detection and Fragmentation Analysis
}

\author{
B.E.S. Bandara*, R.P. De Silva ${ }^{1}$ and N.D.K. Dayawansa ${ }^{1}$
}

\author{
Postgraduate Institute of Agriculture \\ University of Peradeniya \\ Sri Lanka
}

\begin{abstract}
Wilpattu Forest complex is the largest protected area in Sri Lanka and it is a designated Ramsar wetland cluster. It contains a range of diverse terrestrial habitats including various forest types and a coastline with large coastal sand dunes. However, this vital ecosystem is under threat of fragmentation and degradation due to increasing human interventions. Habitat fragmentation is a serious threat to the rich biodiversity in this ecosystem. The objective of this study was to assess the loss of forest cover within the region, to examine the spatial pattern of forest cover fragmentation and to predict the potential forest cover change in 2025 using remote sensing and GIS techniques. Two Landsat 5 TM satellite images of 1992 and Landsat 8 OLI-TIRS image of 2018 were classified using unsupervised and supervised techniques to obtain three land usel land cover classes namely, forest, nonforest and water. Forest cover change during 1992 and 2018 was analysed using classified images. Finally, future changes were modelled to assess possible threat to the forest cover. The analysis revealed that Wilpattu forest complex has lost 19,524 ha of its forest reserves to other land uses within the last 26 years and the highest impact was seen in the upper Wilpattu forest where about $7.48 \%$ area has lost from forest to other land uses. Study also proved that the total forest area is becoming more fragmented affecting the balance of the valuable natural eco-system of the area. Lack of availability in proper forest boundaries and classification issues were identified as main limitations in this study. However, it must be emphasized that immediate actions are needed to prevent further degradation of this sensitive ecosystem.
\end{abstract}

Keywords: Change detection, forest cover, fragmentation analysis, modelling

\section{INTRODUCTION}

Natural ecosystems are vital components of human and animal lives since they provide important goods and services for their existence. However, the ecosystems are under constant threat of degradation or destruction due to increasing human interactions. Forests are one of the major elements of the environment which provide the foundation for life on earth through ecological functions. It regulates the climate and water resources while providing habitats for plants and animals. According to Food and Agriculture Organization of the United Nations (FAO, 2001) the total forest cover in Sri Lanka in 1992 was about 32.2 percent of its total land area. By 2010 Sri Lanka's forest cover has reduced to $26.6 \%$ indicating a land cover of 1.7 million hectares (FAO, 2010). Ratnayake et al. (2002) concluded that four districts, namely Mannar, Puttlam, Trincomalee and Vavuniya are having serious forest cover reduction. FAO

\footnotetext{
${ }^{1}$ Department of Agricultural Engineering, Faculty of Agriculture, University of Peradeniya, Sri Lanka

* Corresponding author: erangasanjayab@gmail.com
}

This is an open-access article distributed under the terms of the Creative Commons Attribution License, which permits unrestricted use, distribution, and reproduction in any medium, provided the original author and source are credited. 
(2010) presented the deforestation rate in Sri Lanka as 1.2\% during 1990-2000 in which $1.47 \%$ reduction has occurred during 2000-2005 and 0.77\% reduction has occurred during 2005-2010. Hewage and Mallika (2008) stated the most serious consequences of deforestation as loss of biodiversity, irregular water supply, shortened lifespan of irrigation channels and reservoirs, soil erosion and loss of soil fertility. Forest fragmentation is one of the serious consequences of deforestation which leads to habitat fragmentation (Laurance, 1998). Fragmentation analysis can be used to quantify the forest cover change. Reddy et al. (2012) stated that fragmentation occurs when large continuous forests are divided into smaller blocks by physical barriers such as roads, agriculture, urbanization or other development activity. Three landscape level metrics can be used for the spatial characterization of the land use/land cover maps. The landscape contagion index (CONTAG) measures the degree of clumping of attributes on raster maps. The index is computed from the frequencies by which different pairs of attributes occur as adjacent pixels on a map (Ritters et al., 1996). Landscape shape index (LSI) is widely used in landscape ecology. It has been introduced to indicate the divergence of the shape of a landscape patch from an ideal shape (Circle) (Patton, 1975). Plant associations of circular shape (shortest perimeter compared to its area patches) within a certain size category are considered as the most stable and resistant in ecological sense. Shannon's diversity index (SHDI) accounts for both abundance and evenness of the species present. Estoque et al. (2016) and Subasinghe et al. (2016) cited that an increase in CONTAG indicates an increase in the degree of clumpiness of patches in terms of configuration and composition of landscape, while a decrease in CONTAG indicates an increase in the level of fragmentation. Contagion Index considers all patch types present in an image, including any present in the landscape border, if present like adjacencies. Increase in LSI value indicates an increase in the degree of landscape disaggregation or dispersion. LSI provides a standardized measure of total edge that adjusts for the size of the landscape. It measures the perimeter to area ratio for the landscape as a whole. The value of SHDI represents the amount of information per patch. SHDI is equal to 0 when the landscape has no diversity. SHDI increases as the number of different patch types increases. To obtain forecasted land use pattern of the area, multi-layer perception neural network (MLP NN) and CA-Markov modules available in the TerrSet GIS software can be used. Markov Chain process, determines the amount of change according to multi temporal land use/ land cover maps. The characteristics of different indices are given in Table 1.

Table 1. Fragmentation indices and their characteristics.

\begin{tabular}{llll}
\hline Metrics & & Units & Range \\
\hline CONTAG & Contagion Index & $\%$ & $0<\mathrm{CI} \leq 100$ \\
LSI & Landscape Shape Index & None & LSI $\geq 1$ \\
SHDI & Shannon's Diversity Index & Information & SHDI $\geq 0$ \\
\hline
\end{tabular}

This study was conducted with the main objective of assessing the forest cover change in Wilpattu National Park area during the time period of 1992-2018 using remote sensing and GIS techniques. The specific objectives were to identify the spatial pattern of forest fragmentation and to predict the potential forest cover change in the future.

\section{METHODOLOGY}

\section{Study area}

The Wilpattu forest belongs to North Central, North Western and Northern provinces of Sri Lanka. Wilpattu Forest Complex is a land area of 213,755 ha and is the largest remaining 
forested land in Sri Lanka (Senewiratne, 2017). The mean annual temperature is $27.2{ }^{\circ} \mathrm{C}$ and total annual precipitation is approximately $1000 \mathrm{~mm}$. The main feature in this area is the concentration of 'villus' or 'lakes' within the Dry Monsoon forest area creating a wetland complex. Wilpattu area nourishes Kala Oya and Malwathu Oya. This forest complex is made up of many separate forest reserves, namely Marichchikaddi-Karadikkuli, Veppal, Mavillu, Vilatthaikulam (here referred as Upper Wilpattu), Wilpattu National Park, Wilpattu North Sanctuary (here referred as Wilpattu) and Thabbova Sanctuary, Veerakkulichol Sanctuary and Eluwankulam Proposed Forest Reserve (here referred as Lower Wilpattu), which was used as the study area. Wilpattu forest complex is a destination for migratory birds. Therefore, the habitat change with time would have a significant impact on biodiversity. Considering this importance, the Department of Wildlife Conservation in Sri Lanka has declared Wilpattu as a Ramsar site in 2013. Illegal settlements and encroachments are affecting the natural forest cover in this area. Environmental Foundation Limited (2017) reported that clearing of forest cover is seen widely on land which belongs to Wilpattu forest complex. Thus, there is an essential need of assessing the forest cover change in the Wilpattu forest complex in order to protect the valuable natural eco system for the future generation.

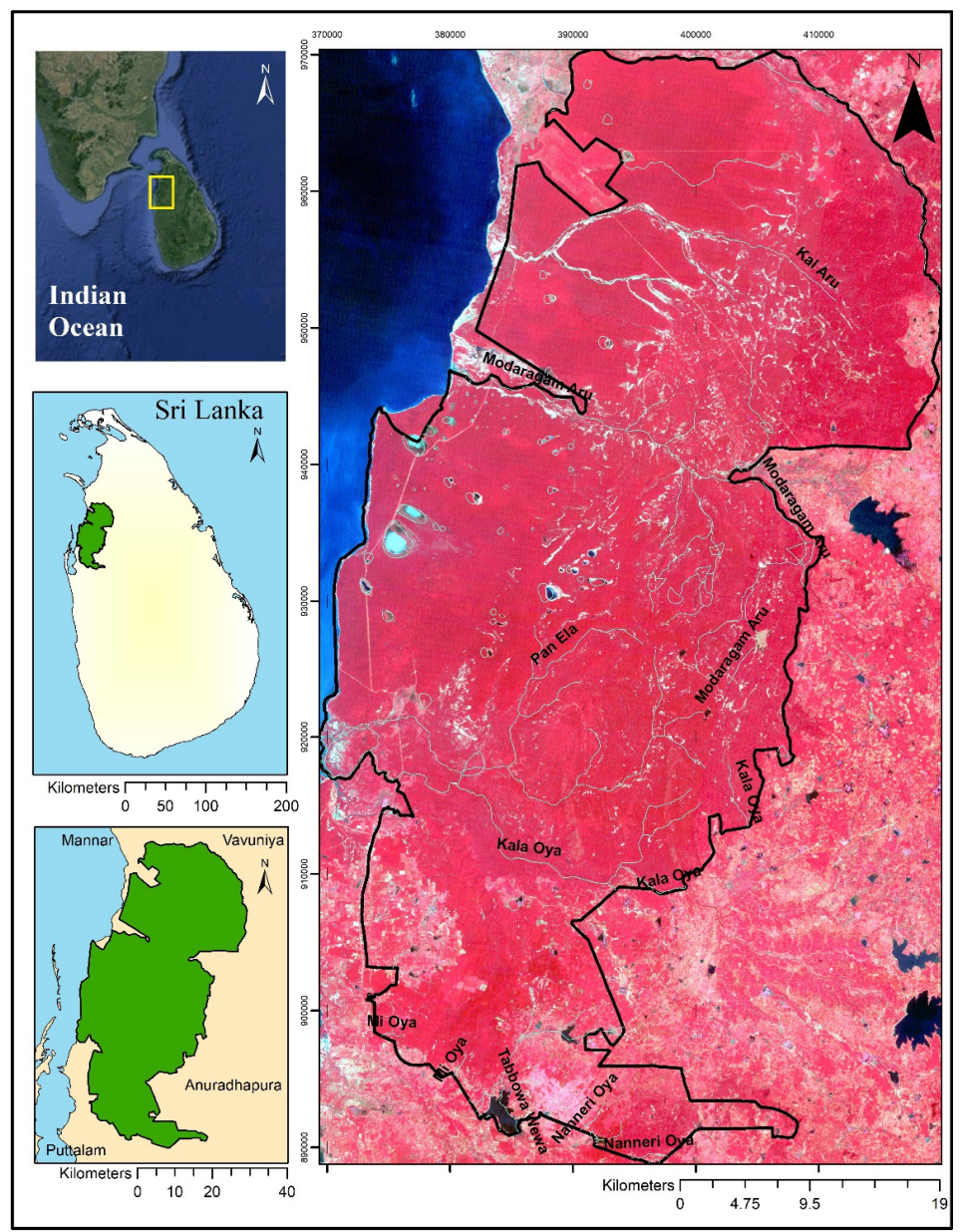

Figure 1. Wilpattu forest complex. 


\section{Satellite imagery and other data}

Landsat satellite images with minimum cloud disturbances $(<10 \%)$ and with a time interval of 26 years were obtained from the United States Geological Survey (USGS) website. Table 2 presents the characteristics of satellite images used in the study.

Table 2. Satellite images and their characteristics

\begin{tabular}{llllll}
\hline Data & Sensor & Date Acquired & Resolution & Path & Row \\
\hline LANDSAT_5 & TM & $1992-01-25$ & $30 \mathrm{~m}$ & 141 & 054 \\
LANDSAT_5 & TM & $1992-02-01$ & $30 \mathrm{~m}$ & 142 & 054 \\
LANDSAT_8 & OLI_TIRS & $2018-01-07$ & $30 \mathrm{~m}$ & 142 & 054 \\
\hline
\end{tabular}

Two satellite images of 1992 were mosaiced and produced one quality image for further processing whereas the second time point needed only one satellite image to cover the study area. Then using the forest boundary, study area was extracted. Figure 2 shows the false colour composites (FCC) $(\mathrm{R}=$ NIR band, $\mathrm{G}=$ Red band, $\mathrm{B}=$ Green band $)$ of multi temporal images.
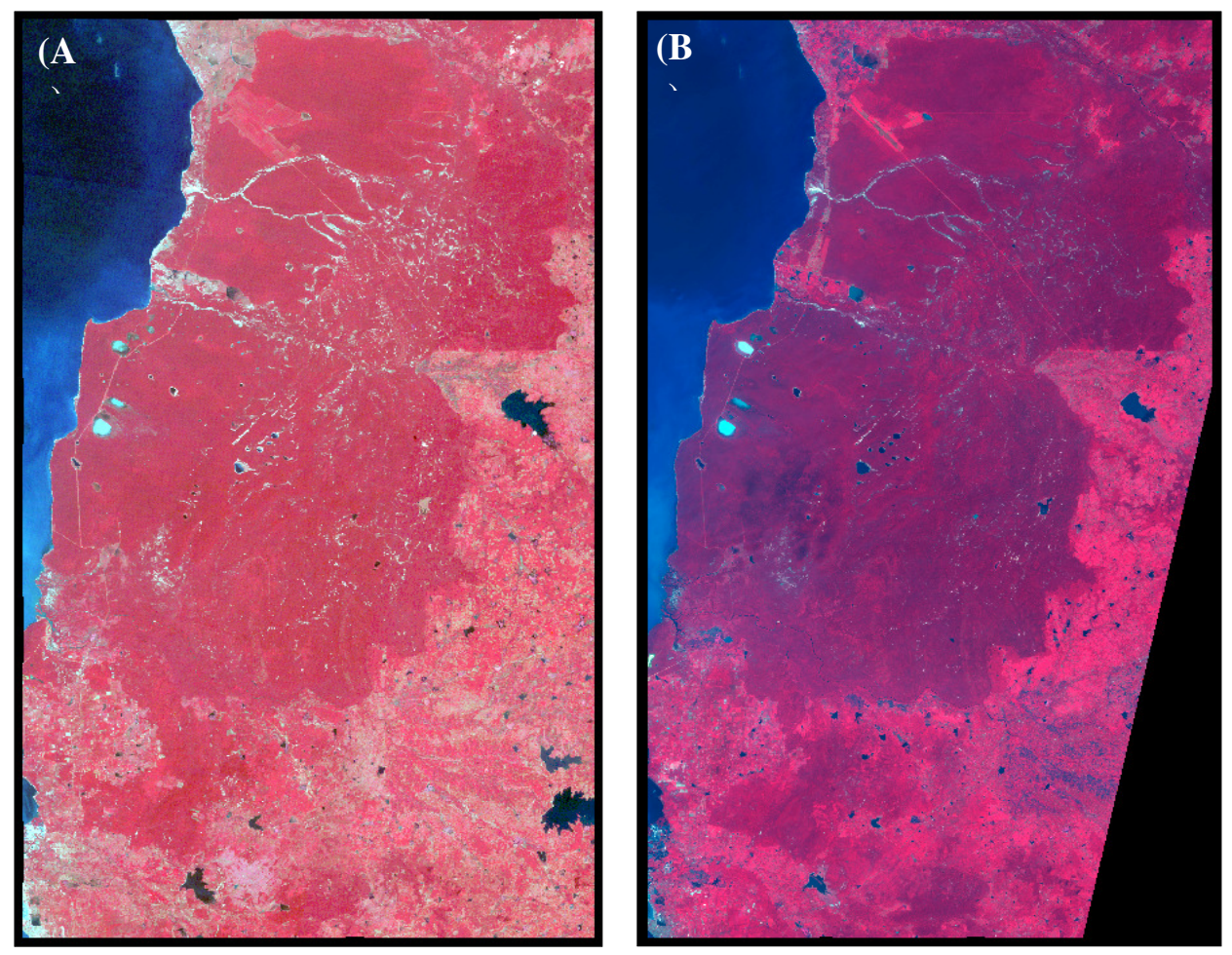

Figure 2. Standard false colour composites (FCC)images of (A) 1992 and (B) 2018.

The satellite image of 1992 was classified into 45 classes using unsupervised classification technique in order to separate the pixel values into details. These classes were combined to 
identify three land use/ land cover classes namely forest, non-forest and water. This 1992 image was classified using unsupervised classification technique because of the lack of ground truth data and a reliable base map to trace the points during this time point. With the help of Google Earth satellite images to collect ground truth, 2018 satellite image was classified into same three land use/ land cover classes using supervised classification. Classification accuracy assessment was carried out considering Google Earth images as a reference.

Final classified images contained three classes namely, Forest, Non Forest and Water. These classified images of two time points were subjected to further analysis to assess land use/ land cover changes, forest fragmentation, zonal analysis and land use/ land cover predictions.

\section{Forest fragmentation analysis}

The landscape-level metrics namely, CONTAG, LSI and SHDI were calculated using Fragstats 4.1 software. Figure 3 presents the flow diagram of the methodology adopted in the study.

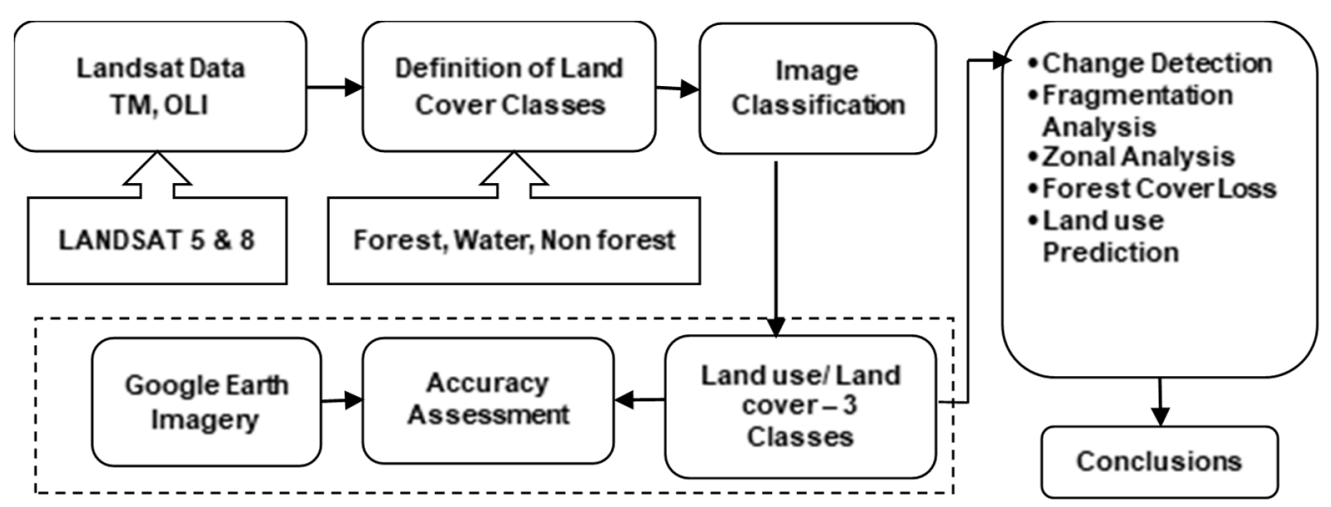

Figure 3. Flow diagram showing of the study methodology.

\section{RESULTS AND DISCUSSION}

\section{Land use/ land cover changes}

Timely and accurate change detection of land use features is very important for understanding relationships and interactions between human and natural phenomena in order to promote better decision making. In this study, land use/ land cover changes were assessed using ArcGIS software. The changes were identified in categories as FF (Forest Unchanged), FW (Forest to Water), FN (Forest to Non-forest), WF (Water to Forest), WW (Water Unchanged), WN (Water to Non-forest), NF (Non-forest to Forest), NW (Non-forest to Water) and NN (Nonforest Unchanged). Three categories present as FF, WW and NN are the unchanged areas and the other six categories present the changed areas. Table 3 presents the land use/ land cover change matrix and Figure 4 presents the changes in land use/ land cover. 
Table 3. Land use/ land cover change matrix.

\begin{tabular}{llll}
\hline$\#$ & Description & \multicolumn{1}{c}{ Area (ha) } & \% \\
\hline 1 & Forest No Change & $158,451.8$ & $75.00 \%$ \\
2 & Forest into Water & 56.5 & $0.03 \%$ \\
3 & Forest into Non-forest & $19,523.8$ & $9.24 \%$ \\
4 & Water Unchanged & 1,677 & $0.79 \%$ \\
5 & Water into Forest & 27.8 & $0.01 \%$ \\
6 & Water into Non forest & $1,128.7$ & $0.53 \%$ \\
7 & Non forest Unhanged & $21,054.3$ & $9.97 \%$ \\
8 & Non forest into Forest & $9,139.9$ & $4.33 \%$ \\
9 & Non forest into Water & 199.3 & $0.09 \%$ \\
\hline
\end{tabular}

As shown in the Table 3 an area about 158451 ha of forest has remained as forest over the time. Approximately 19524 ha of land has changed from Forest to other land use/ cover classes. Since there were some seasonal effects on the satellite images used in extracting land use/ land cover classes, some pixels were incorrectly classified and those pixels were omitted in change analysis. About $4 \%$ of the area has changed from other land uses to forest since some adjacent areas were also named as protected area by the law.

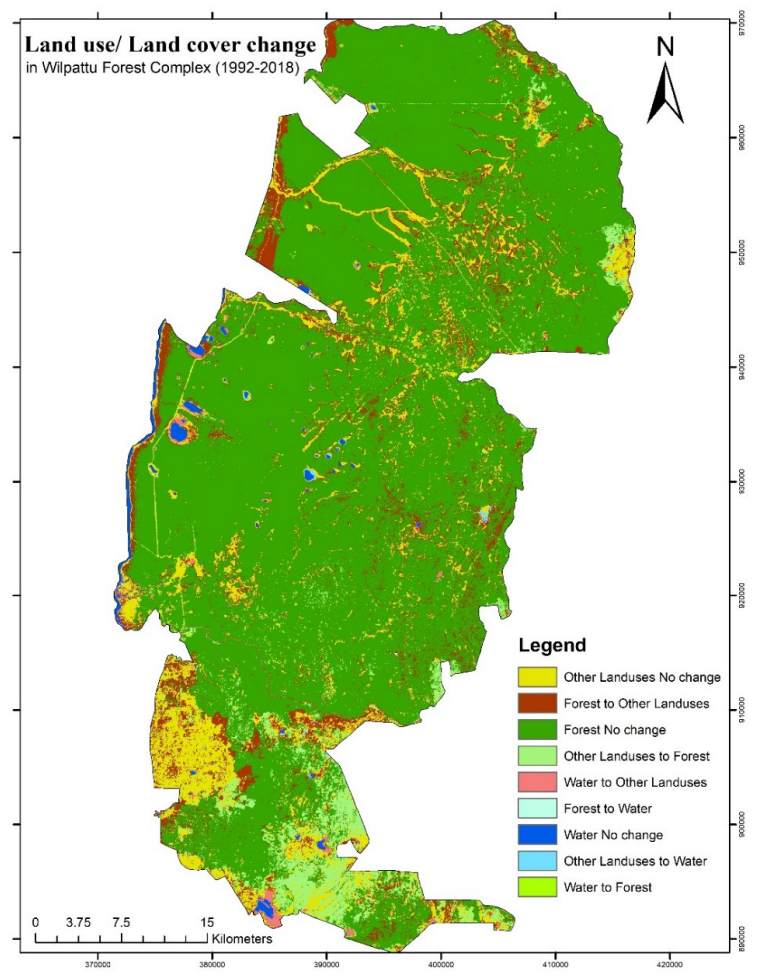

Figure 4. Land use/ land cover changes from 1992 to 2018 in Wilpattu Forest Complex. 


\section{Forest cover loss}

The loss of forest cover from 1992 to 2018 is shown in Figure 5. As marked in the Figure 5, area number 1 and 2 shows the deforested areas for construction of houses. These zones are referred as area for resettlements though they are located within the forest complex. Area 3 marked in Figure 5 is the area which were already encroached and it is evident that the encroachment is further approaching towards the heart of the forest. According to the classification, all together an area of 19,524 ha forest cover loss has happened within the Wilpattu forest complex over the 26 year period.

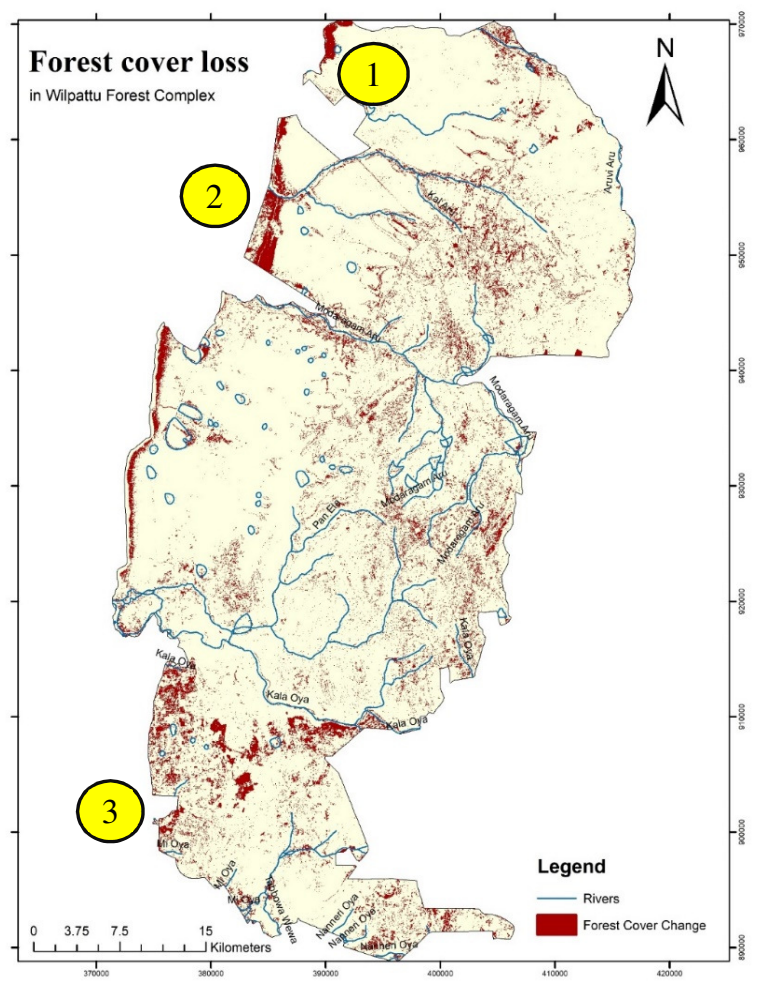

Figure 5. Forest cover loss in Wilpattu Forest Complex.

\section{Fragmentation of Wilpattu forest complex}

Figure 6 presents the LSI, SHDI and CONTAG indices calculated for 1992 and 2018 land use/ land cover condition in Wilpattu forest complex.

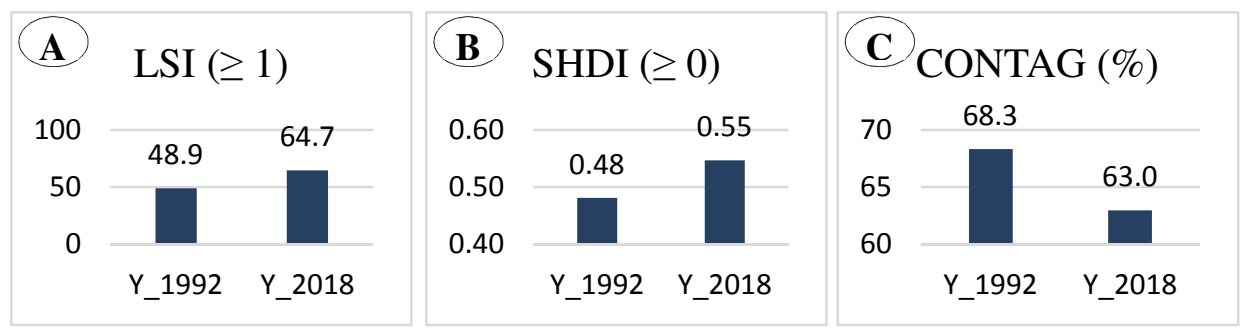

Figure 6. Temporal differences of (A) LSI, (B) SHDI and (C) CONTAG indices. 
As shown in Figure 6 (A), LSI values increased from 48.9 to 64.7. This indicated a temporal increase of perimeter values of different classes. This showed that patches were disaggregated in 2018 compared to 1992. The value of SHDI represents the amount of information per patch. As shown in Figure 6(B), the values increased from 0.48 to 0.55 . That denoted an increase in the diversity of the distribution of classes. To increase the diversity, there should be different adjacent classes. This showed a discontinuity of patches casused by the land fragmentation. CONTAG values were reduced over time (Figure $6(\mathrm{C})$ ) from $68.3 \%$ to $63 \%$ indicating an increase of dispersed patches. The construction of road system joining the Villu's and other key points is the main cause for the fragmentation. The adjacent cell values differ in 2018 compared to 1992. All of the indices revealed that the landscape has been fragmented and this was further visualized by the classified images of 1992 and 2018.

\section{Zonal analysis}

Zonal analysis was performed by dividing the Wilpattu forest complex into three segments based on the Wilpattu national park and its upper and lower adjacent forest reserves (Figure 7).

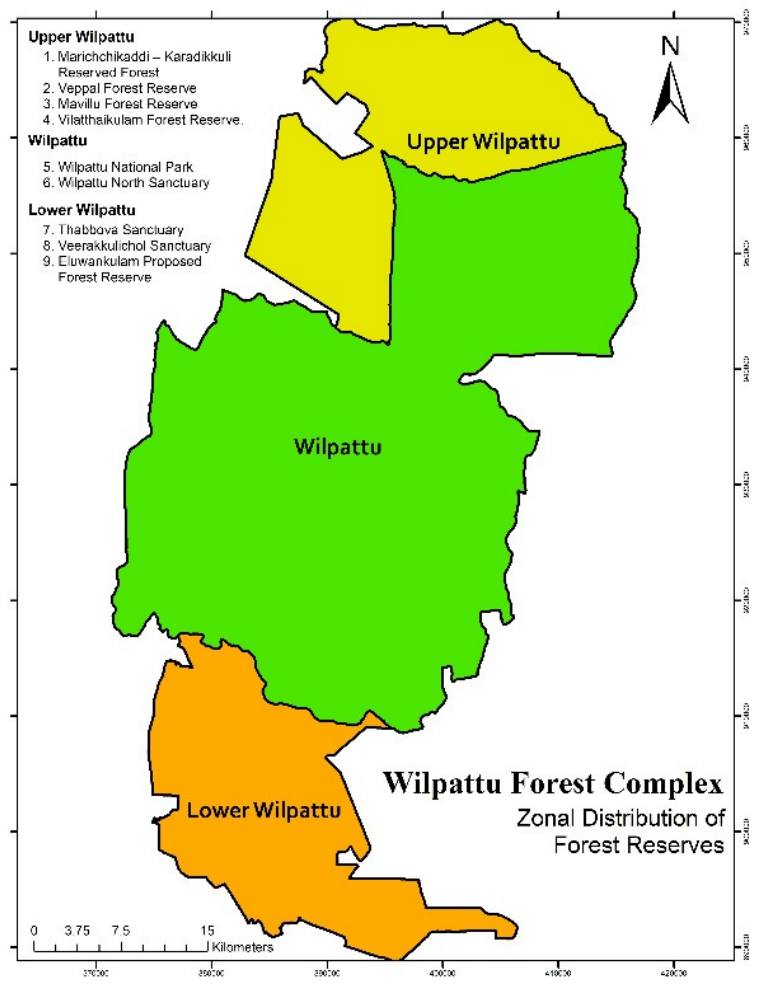

Figure 7. Zonal Distribution of forest reserves in Wilpattu forest complex.

Figure 8 illustrates the percentages of forest and non-forest areas in each zone. From those values, frequency of each class was derived. Maximum change of the forest cover has occurred in the Upper Wilpattu area. Even the area covered by Upper Wilpattu area is smaller in extent and the highest percentage of forest cover loss is visible there. Illegal clearing of forest cover has been reported in Upper Wilpattu area. 


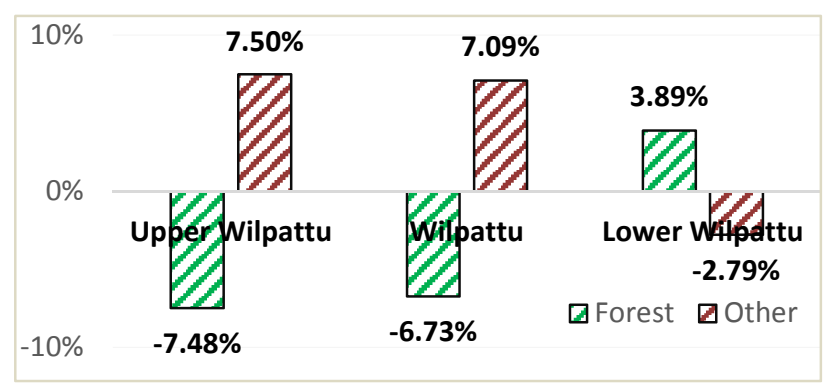

Figure 8. Forest and other land uses (non forest and water) changes over time.

\section{Modelling the future land use pattern}

As shown in Figure 9, classified images with three classes from two time points (1992 and 2018) were used in CA-Markov model to predict the future land use for year 2025. The model analyzed the changes from land use/ land cover images of 1992 and 2018. It provides net gains and losses and all the statistics related to changes within the two time points. Then the land cover change sub models were created based on the classes such as F (Forest) to N (Nonforest), $\mathrm{W}$ (Water) to $\mathrm{N}$, etc. In order to run the sub model, the driver variables were specified in this phase. Driver variables (Figure 11 and 12) were created using the Euclidean distance from the boundary of forest complex to the existing road network, existing land plots and existing non forest areas since these variables have visible changes with the time.

After giving all the inputs as mentioned in the above, the model simulated the future land use/ land cover with two outputs as soft prediction and hard prediction as shown in Figure 10. Soft prediction depicts the vulnerability of each pixel to transition to different land cover classes during the time period specified. In the transitional potential map, areas in red have a high potential to transition whereas areas in green have a low potential to transition. The map shows that a considerable extent of land in the forest complex has a high potential to transition indicating the vulnerability of this ecosystem for changes. In the hard prediction map, the lower Vilpattu area consists of a considerable extent of other land uses indicating forest cover loss. According to the prediction, the changes to other land uses from forest is prominent along the road network. Hence, construction of new roads within this ecosystem will make it more vulnerable to forest cover loss. 

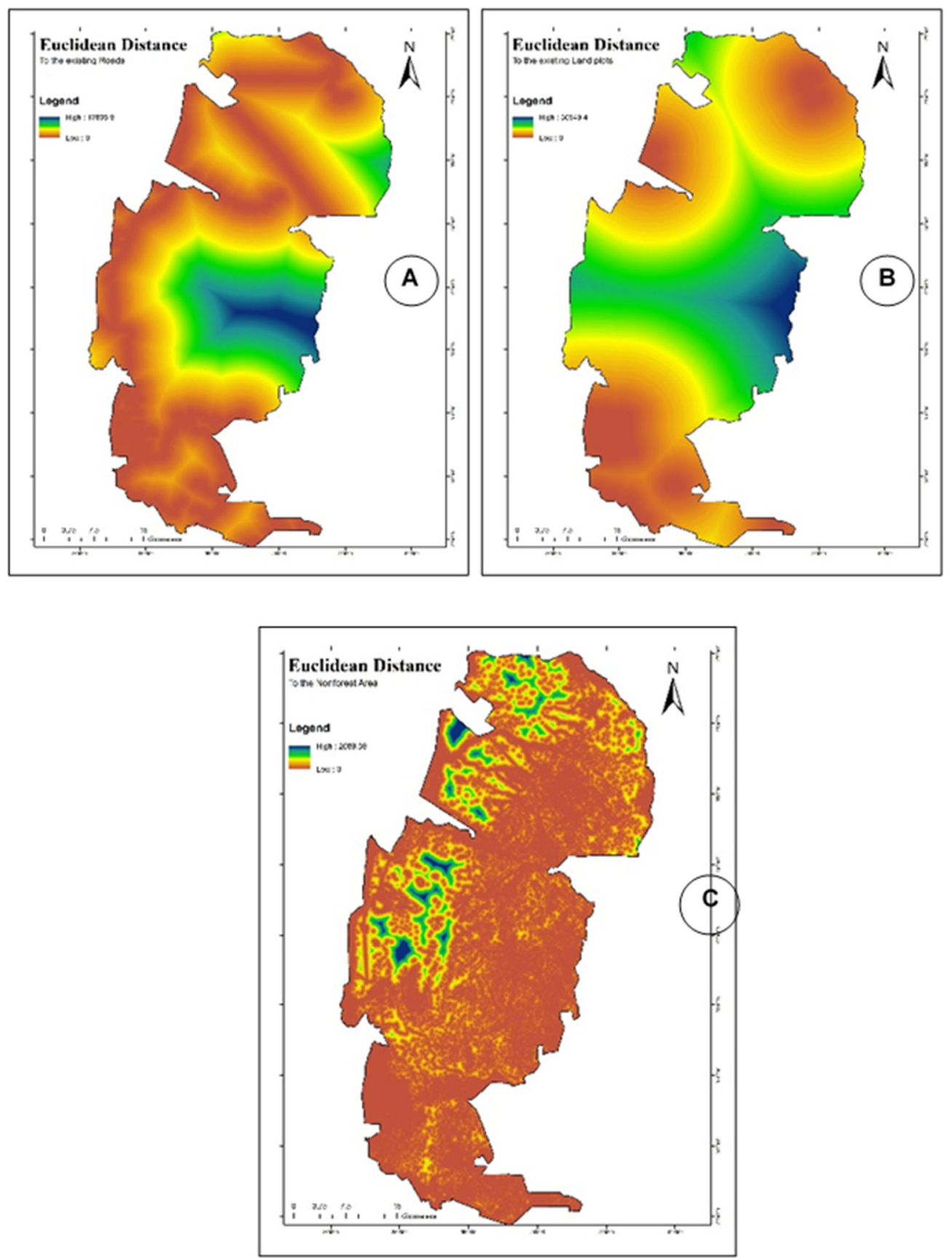

Figure 9. Driver Variables A: Distance to Roads B: Distance to Land plots C: Distance to Non Forest area 

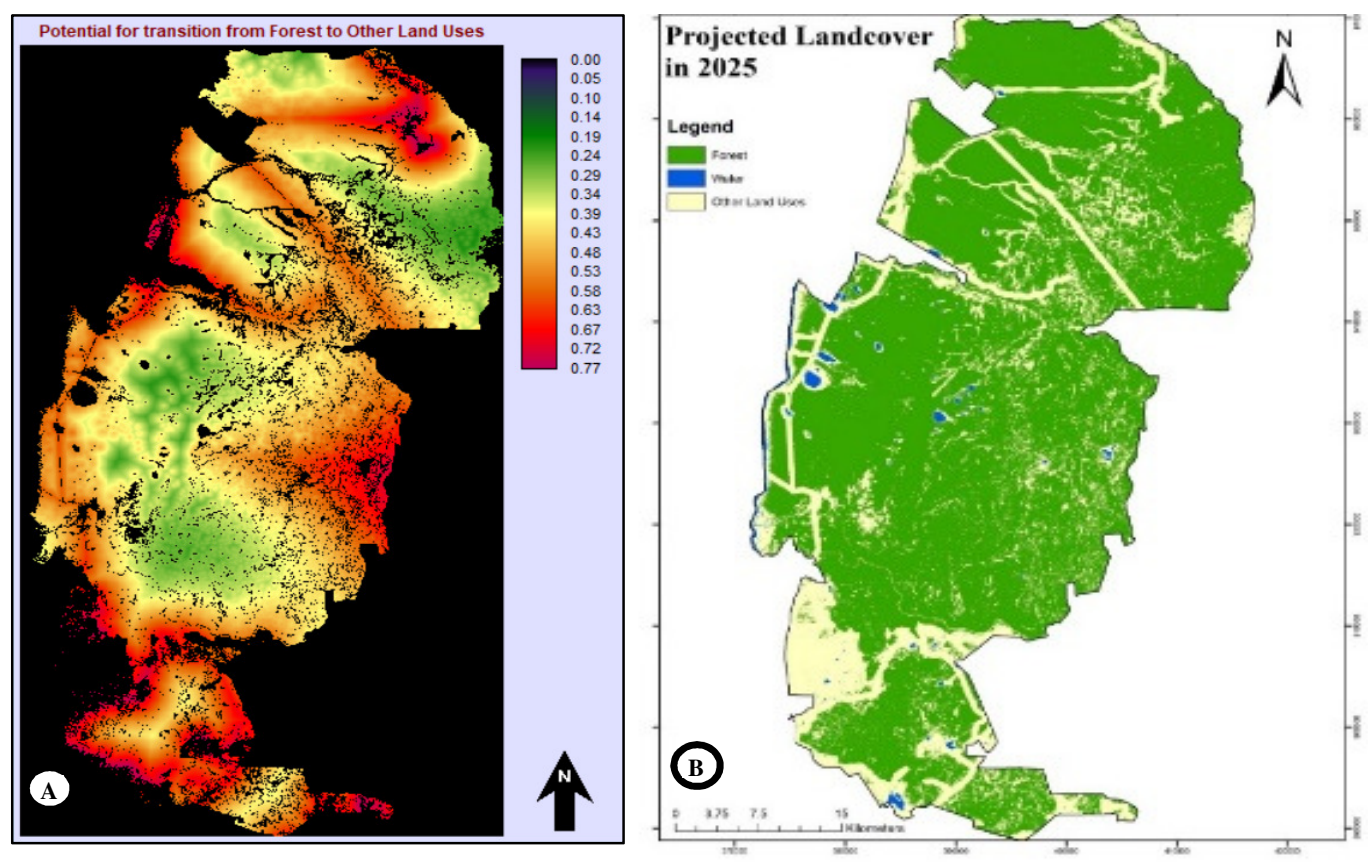

Figure 10. Prediction of Future Land use in Wilpattu Forest Complex A: Soft prediction B: Hard prediction

\section{CONCLUSIONS}

This study analysed the loss of forest cover within Wilpattu forest complex, examined the spatial pattern of forest cover fragmentation and predicted the potential forest cover change by 2025 using remote sensing data and GIS techniques. The analysis revealed that out of 211,259.16 ha land area of Wilpattu forest complex 19,524 ha has been deforested within the past 26 years' time. Study also proved that the total forest area is more fragmented than previous increasing the risk of distorting the balance of the valuable natural eco-system of the area.

\section{REFERENCES}

Environmental Foundation Limited (2017). Deforestation - North of Wilpattu National Park. Site Visit Report. Colombo.

Estoque, R. and Murayama, Y. (2016). Quantifying landscape pattern and ecosystem service value changes in four rapidly urbanizing hill stations of Southeast Asia. Landscape Ecology. 31 (7), 1481-1507.

FAO (2001). Forest Resources of Sri Lanka Country Report [online]. [Accessed 12 Jan. 2018]. Available at: http://www.fao.org/docrep/007/ad678e/ AD678E02.htm.

FAO (2010). Global Forest Resources Assessment 2010 Country Report Sri Lanka [online]. [Accessed 16 Jan. 2018]. Available at: http://www.fao.org/docrep/013/ al632E/al632e.pdf. 
Hewage, T. and Mallika, K. (2008). Current Trends in Forest and Environmental Policies in Sri Lanka. Proceedings of International Forestry and Environment Symposium [online]. [Accessed 16 Jan 2018], Available at http://journals.sjp.ac.lk/index.php/fesympo/article/view/ $52 / 24$.

Laurance, W.F. (1998). A crisis in the making: responses of Amazonian forests to land use and climate change. Trends in Ecology and Evolution. 13, 411-415.

Ratnayake, J., Abeykoon, M. and Chemin, Y. (2002). District-wise forest area variation in Sri Lanka from 1992 to 2001 for supporting the National Physical Planning Policy [online]. [Accessed 16 Jan 2018]. Available at http://www.a-a-r-s.org/acrs/proceeding/ACRS2002 /Papers/FR02-3.pdf.

Reddy, C., Jha, C. and Dadhwal, V. (2012). Assessment and monitoring of long-term forest cover changes in Odisha, India using remote sensing and GIS. Environmental Monitoring and Assessment. 185 (5), 4399-4415.

Riitters, K. H., O’Neill, R. H., Wickham, J. D. and Jones, K. B. (1996). A note on contagion indices for landscape analysis, Landscape Ecology. 11, 197-202.

Senewiratne, R. (2017). Importance of standing against deforestation of Wilpattu Forest Complex. [online]. [Accessed 20 Feb. 2018]. Available at: https://www.change.org/p/stopdeforestation-in-wilpattu-forest-complex/u/22183690

Subasinghe, S., Estoque, R. and Murayama, Y. (2016). Spatiotemporal Analysis of Urban Growth Using GIS and Remote Sensing: A Case Study of the Colombo Metropolitan Area, Sri Lanka. ISPRS International Journal of Geo-Information. 5(11), 197-199.

(IUCN) (2006). Resource Inventory of Wilpattu National Park. Final Report, The World Conservation Union, Sri Lanka.

Patton, D. R. (1975). A diversity index for quantifying habitat 'edge'. Wildlife Society Bulletin. 3, 171-173. 